\title{
THE EFFECT OF RHIZOBIUM INOCULATION AND NITROGEN APPLICATION ON VARIOUS AGRONOMICAL AND QUALITY CHARACTERISTICS OF PEANUT GROWN AS A MAIN CROP
}

\author{
Ferrin Ferda ASIK ${ }^{*}$, H. Halis ARIOGLU ${ }^{2}$ \\ ${ }^{1}$ Karacabey District Directorate of Agriculture and Forestry, Bursa, TURKEY \\ ${ }^{2}$ Çukurova University, Faculty of Agriculture, Department of Field Crops, Adana, TURKEY \\ *Corresponding author: ferrinferda.asik@tarimorman.gov.tr
}

Received: 14.08 .2020

\begin{abstract}
The objective of this study was to determine the effect of nitrogen fertilizer and bacteria inoculation on some agronomic and quality characteristics of Halisbey peanut cultivar. This study was conducted at the Applying and Research Area of Field Crops Department, Faculty of Agricultural, Çukurova University in 2015 and 2016. The experimental design was a randomized block design. In this study, seven $(0,40,80,120,160,200$ and $240 \mathrm{~kg} \mathrm{ha}^{-1}$ ) different nitrogen doses and Rhizobium bacteria were used. As a result of study, the pod yield varied between $4702-6009 \mathrm{~kg} \mathrm{ha}^{-1}$. The highest pod yield was obtained from $200 \mathrm{~kg} \mathrm{ha}^{-1}\left(6009 \mathrm{~kg} \mathrm{ha}^{-1}\right)$ nitrogen and $200 \mathrm{~kg} \mathrm{ha}^{-1}$ nitrogen + bacteria $\left(6001 \mathrm{~kg} \mathrm{ha}^{-1}\right)$ applied plots. The lowest pod yield $\left(4702 \mathrm{~kg} \mathrm{ha}^{-1}\right) \mathrm{was}^{-1}$ obtained from control plots (without $N$ and $B$ ). Pod number per plant, pod weight per plant, 100 pod weight, protein, oil ratio and pod yield per ha were affected by the160 and $200 \mathrm{~kg} \mathrm{ha}^{-1}$ nitrogen applications. Also, the highest protein ratio was obtained from the $240 \mathrm{~kg} \mathrm{ha}^{-1}$ nitrogen and bacteria inoculation.
\end{abstract}

Keywords: Bacteria, nitrogen fertilization, peanut, pod yield and quality

\section{INTRODUCTION}

Peanut (Arachis hypogaea L.) is a annual and summer oil plant belonging to the leguminous family. It is a significant food for human nutrition due to its valuable nutrients contents such as oil, protein, carbohydrates and vitamins. Peanut seeds contain $43-55 \%$ oil, $25-28 \%$ protein $18 \%$ carbohydrate along with abundant mineral elements such as $\mathrm{K}, \mathrm{Ca}, \mathrm{Mg}, \mathrm{P}$ and $\mathrm{S}$. Besides, it is rich in vitamins like A, B (Niacin, Inositol etc) and $\mathrm{E}$ (Tocofherol) (Woodroof, 1983; Maiti and Ebeling, 2002).

The peanut cultivation area in the world was 26.3 million ha, the production was 45.5 million tons and the average yield per hectare was $1740 \mathrm{~kg}$. China, India, Nigeria, USA, Sudan, Tanzania, Argentina and Myanmar are considered as the first countries in the world's peanut production according to the data of 2017 (FAO, 2017).

In our country, peanut cultivation has been made in the area of 4195 hectare with a yield of 165.330 tons product and $3940 \mathrm{~kg}$ shelled peanuts per hectare (TUIK, 2017). Peanut production is carried out mostly in the provinces located within the Mediterranean region. Adana, Osmaniye, Içel, Antalya, Kahramanmaras, Aydın and Mugla provinces are regarded as the first provinces in Turkey in terms of the production of peanuts.
Since peanut is a legume plant and contains a high proportion of protein in its seeds, it removes a high amount of nitrogen from the soil. The studies have shown that peanut plant fixed $45-150 \mathrm{~kg} \mathrm{ha}^{-1}$ nitrogen $(\mathrm{N})$ during the growing period (Woodroof, 1983). Nitrogen, which is fixed by Rhizobium bacterium, is stored as nodules in plant roots. A large part of this nitrogen is used by the plants and $30-40 \%$ of it remains in the soil (Arioglu, 2014). The peanut plant uptake the needed nitrogen from the soil and an important part of it from free nitrogen in the air thanks to the Rhizobium sp. bacterium available in its roots (Uyanik et al., 2011). Owing to symbiotic Rhizobium sp. bacteria, it fixed the free nitrogen of the air to the soil. In the areas where peanut cultivation is performed, the nitrogen required by the plant is provided by fertilization due to the lack of Rhizobium bacterium in the soil. However, the expected level of the product cannot be obtained because of the insufficient amount of applied nitrogen fertilizer. This can be due to the fact that farmers do not use fertilizer based on soil analysis and they do not take into account the loss caused by soil properties in nitrogen fertilizers and climate factors. The symbiotic nitrogen fixation carried out by Rhizobium bacterium is of great significance in the production of peanut due to the environmental problems that arise during the production and use of mineral nitrogen 
fertilizers as well as the expensiveness and difficulty in the application of mineral nitrogen.

Reddy and Tanner (1980) have investigated the effects of $\mathrm{N}$ fertilizer on protein ratio and pod and seed yield. As a result, they have indicated that $\mathrm{N}$ fertilizer applied at different times and doses does not have an effect on pod and seed yield alone. However, $\mathrm{N}$ fertilizer and inoculants have been identified to affect $\mathrm{N}$ and protein content of seed and decrease $\mathrm{N}$ fixation when used together with the bacterium. Rhizobium inoculation and nitrogen fertilizer application are generally more effective and cheaper agricultural practices in order to ensure adequate nitrogen feeding in legumes (Burton, 1982). Hiltbold et al. (1983) have applied control, granular inoculant and $56 \mathrm{~kg}$ of $\mathrm{N}$ $\mathrm{ha}^{-1}$ (ammonium nitrate) during plantation. Research results have revealed that only bacterium inoculation has no effect on root development, leaf colour and seed nitrogen content, yet it has been found to increase pod number and pod weight per plant when applied together with $\mathrm{N}$ fertilizer during planting; moreover, bacterium inoculation and $\mathrm{N}$ fertilizer increased pod yield from 130 $\mathrm{kg} \mathrm{ha}^{-1}$ to $590 \mathrm{~kg} \mathrm{ha}^{-1}$. Mahalle et al. (1992) determined that $25 \mathrm{~kg} \mathrm{~N}^{-1}$ application increased fruit yields from $1520 \mathrm{~kg} \mathrm{ha}^{-1}$ to $1750 \mathrm{~kg} \mathrm{ha}^{-1}$, and $50 \mathrm{~kg} \mathrm{~N} \mathrm{ha}^{-1}$ application did not have a significant effect on fruit yield. Lanier et al. (2004), in a study they conducted with bacteria, nitrogen fertilizers and commercial granules or liquid inoculants, found that bacterium application has the highest pod yield in 7 of the 20 experiments, while nitrogen fertilizer has the highest pod yield in 3 of 6 experiments. Hickey et al. (1974) reported that the fruit yield of Florunner peanuts grown by inoculating bacteria increased from $1908 \mathrm{~kg} \mathrm{ha}^{-1}$ to $3703 \mathrm{~kg} \mathrm{ha}^{-1}$. Gok et al. (2007) determined that nodulation and nitrogen fixation is very weak when bacterial inoculation is not performed or neglected for a long time.

The aim of this study is to determine the effect of bacteria inoculation and different doses of nitrogen fertilizer applications on yield and some agricultural and quality characteristics in the main crop peanut cultivation under Cukurova conditions. According to the results to be obtained, the correct fertilizer recommendations can be made to the producers.

\section{MATERIALS AND METHOD}

This research has been conducted under the main crop conditions at the Research and Experimental Field of the Department of Field Crops, Faculty of Agriculture of Cukurova University, in 2015 and 2016. Halisbey variety, nitrogen fertilizers such as Ammonium Sulfate, Ammonium Nitrate and Rhizobium bacterium were used as materials. The average air temperature, total precipitation and relative humidity and the long-term averages of the growing period in 2015 and 2016 are given in Table 1.

Table 1. Temperature, precipitation and relative humidity values of experimental years and long-term growing seasons in Adana Province

\begin{tabular}{llllllllll}
\hline Climate & Years & April & May & June & July & August & September & October & Av. \\
\hline Average & $\mathbf{2 0 1 5}$ & 16.9 & 22.5 & 25.0 & 28.4 & 30.0 & 28.4 & 23.4 & 16.9 \\
Temperature & $\mathbf{2 0 1 6}$ & 20.5 & 21.6 & 27.1 & 29.5 & 29.9 & 26.3 & 23.1 & 20.5 \\
$\left({ }^{\mathbf{C} C)}\right.$ & Long & 13.8 & 17.7 & 22.0 & 26.0 & 28.7 & 29.3 & 26.4 & 13.8 \\
\hline term & $\mathbf{2 0 1 5}$ & 21.5 & 65.7 & 4.8 & 0.4 & 10.9 & 130.0 & 32.1 & 21.5 \\
$\begin{array}{l}\text { Precipitation } \\
(\mathbf{m m})\end{array}$ & $\mathbf{2 0 1 6}$ & 36.6 & 87.9 & 45.6 & 0.2 & 8.2 & 39.8 & - & 36.6 \\
\hline Relative & term & 44.5 & 44.7 & 15.1 & 4.7 & 7.4 & 24.4 & 37.8 & 44.5 \\
$\begin{array}{l}\text { Humidity } \\
(\%)\end{array}$ & $\mathbf{2 0 1 5}$ & 61.2 & 64.8 & 69.6 & 69.8 & 63.4 & 64.8 & 63.7 & 61.2 \\
& $\mathbf{2 0 1 6}$ & 59.2 & 69.3 & 66.1 & 67.5 & 69.0 & 61.8 & 56.4 & 59.2 \\
\hline
\end{tabular}

*: Climate data provided from Adana Meteorology Services General Directorate

Cukurova Region is under the influence of the Mediterranean climate which is hot and dry in the summer time and warm and rainy in winters. It is seen that the monthly average temperature values of 2016 are slightly higher than the air temperature values of 2015 growing period. The total amount of precipitation during the 2015 growing period is below the amount of precipitation during the average rainfall period of many years. On the other hand, the amount of precipitation May, June and September in 2016 year is above the long-term average precipitation.
The soils of experiental area is in the Menzilat soil series (Dingil et al., 2008). It has been determinated that the soils have a loamy structure, the $\mathrm{pH}$ (7.76) is slightly alkaline, very high in lime $(23.21 \%)$, insufficient in terms of organic matter and salt-free. The total $\mathrm{N}$ content is at a medium with $(0.100-0.064 \%), \mathrm{K}$ content is at sufficient and high level and Fe content is too little and very low level (Table 2). 
Table 2. Some physical and chemical characteristics of the soils of the experimental site

\begin{tabular}{lcc}
\hline Properties & Year 2015 & Year 2016 \\
\hline Depth $(\mathrm{cm})$ & $0-30$ & $0-30$ \\
Texture & Loam & Loam \\
Reaction, $\mathrm{pH}$ & 7.76 & 7.76 \\
$\mathrm{EC}, \mu \mathrm{S} \mathrm{cm}{ }^{-1}$ & 565.0 & 624.3 \\
Lime, $\mathrm{CaCO}_{3}, \%$ & 23.21 & 14.47 \\
Organic matter $(\%)$ & 1.50 & 1.88 \\
Total $\mathrm{N}(\%)$ & 0.100 & 0.064 \\
Available $\mathrm{P}_{2} \mathrm{O}_{5}\left(\mathrm{~kg} \mathrm{da}^{-1}\right)$ & 7.65 & 10.05 \\
Exc. K $\left(\mathrm{kg} \mathrm{da}^{-1}\right)$ & 52.6 & 86.9 \\
DTPA-Fe $\left(\mathrm{mg} \mathrm{kg}^{-1}\right)$ & 2.03 & 7.04 \\
DTPA- Cu $\left(\mathrm{mg} \mathrm{kg}^{-1}\right)$ & 0.71 & 2.09 \\
DTPA-Mn $\left(\mathrm{mg} \mathrm{kg}^{-1}\right)$ & 5.06 & 7.41 \\
DTPA-Zn $\left(\mathrm{mg} \mathrm{kg}^{-1}\right)$ & 0.56 & 2.96 \\
\hline
\end{tabular}

Field experiments were carried out in 2015 to 2016 during the growth period (April-September) The experimental design was a Randomized Complete Block with three replications. The experimental area was mixed with the plow in the autumn and made ready for planting by the cultivator in the spring.

According to soil analysis before planting, $100 \mathrm{~kg} \mathrm{ha}^{-1}$ $\mathrm{P}_{2} \mathrm{O}_{5}$ was applied using Triple Super Phosphate (42-44\% $\mathrm{P}_{2} \mathrm{O}_{5}$ ) fertilizer and mixed with goble disc. In addition, the experiment area was treated with $1000 \mathrm{cc} \mathrm{ha}^{-1}$ Spectrum EC (Dimethanamid-P) against weeds, and the seeds were treated with Dursban 25 WP (Chlorpyrifos-Ethyl) against subsoil pests and it was disinfected with Captan against seed-borne diseases.

In the experiment, the size of the plot was $2.8 \mathrm{~m} \times 5 \mathrm{~m}$. (total plot area was $14 \mathrm{~m}^{2}$ ), and each plot included 4 rows. The interrow before planting was determined to be $70 \mathrm{~cm}$ with markers and the over rows were determined as 15 $\mathrm{cm}$. The sowing was done by hand between 12 April 2015 and 12 May 2016. According to the planned applications, nitrogen fertilizers, Ammonium Sulphate $(21 \% \mathrm{~N})$ during planting (April 12, 2015 and May 12, 2016) and Ammonium Nitrate $(33 \% \mathrm{~N})$ after sowing (June 27-July 12, 2015 and June 30-July 14, 2016) were applied twice (maximum and in the last flowering period) and directly mixed into the soil. Seven different nitrogen doses such as control, 40, 80, 120, 160, 200 and $240 \mathrm{~kg} \mathrm{ha}^{-1}$ were applied in this study.

Bacterium applications were made directly to the soil with the seed sowing. Sprinkler irrigation was carried out in order to provide sufficient germination after planting. During the growing period, the necessary maintenance works (hoeing, irrigation and spraying) were conducted in a timely manner in accordance with the technique. The maturity status of the pre-harvest fruits was determined according to the "peeling method" and when $60 \%$ of the fruits matured, the plants in the plots were pulled manually and the harvest was carried out on 17 September 2015 and 3-4 October 2016. During the harvest, 20 plants were taken randomly on the side rows of each plot and necessary observations and measurements were made on them. All of the remaining plants in the middle two rows were harvested, dried and weighed and plot yields were determined. The following characteristics measured in the study;

Number of pod (number plant $^{-1}$ ): The total pod of the 20 harvested plants was counted and divided by the number of plants, and the mean value was calculated.

Pod weight (g plant $\left.{ }^{-1}\right)$ : All pod of 20 harvested plants was weighed and divided by the number of plants, and the mean value was calculated.

100-Pod weight (g): 4 pieces of 100 pods were counted from each harvested plot, they were weighed on assay balance and their mean was calculated.

Protein ratio (\%): Total nitrogen ( $\mathrm{N}$ analysis) in peanuts was made according to the Kjeldahl method. The protein in the grain, which is one of the quality characteristics, was calculated by multiplying with the factor of 6.25 after the total $\mathrm{N}$ was found and the protein ratio $\%$ in the grain was calculated.

Oil ratio (\%): The oil ratio was calculated by dissolving grinded peanut seed samples in ether through soxhelet device.

Pod yield ( $\left.\mathrm{kg} \mathrm{ha}^{-1}\right)$ : All of the plants in the middle two of each plot were harvested, weighed, and the yield of pod per hectare was calculated as $\mathrm{kg} \mathrm{ha}^{-1}$ by taking plots to yield into account.

\section{RESULTS AND DISCUSSION}

The results of analysis of variance of parameters are shown in Table 3 . It could be seen in Table 3 that the mean squares for the number of pod per plant, the pod weight per plant, the 100 pod weight, the protein ratio, the oil ratio and the pod yield per hectare were statistically significant.

The pod weight per plant, the 100 pod weight, the protein ratio, the oil ratio and the pod yield per hectare were significant for years. However the number of pod per plant was not found statistically significant in terms of years. Only the interaction variance of year $\mathrm{x}$ treatment was significant for the pod yield per hectare whereas the number of pod per plant, the pod weight per plant, the 100 pod weight, the protein ratio, the oil ratio were not statistically significant. 
Table 3. Results of the analysis of variance for characteristics observed in the trial conducted in 2015 and 2016

\begin{tabular}{|c|c|c|c|c|c|c|c|}
\hline $\begin{array}{l}\text { Source of } \\
\text { variation }\end{array}$ & d.f. & $\begin{array}{c}\text { Pod Number } \\
\text { plant }^{-1}\end{array}$ & $\begin{array}{c}\text { Pod weight } \\
\text { plant }^{-1}\end{array}$ & $\begin{array}{c}100 \text { pod } \\
\text { weight } \\
(\mathrm{g})\end{array}$ & $\begin{array}{c}\text { Protein } \\
\text { ratio } \\
(\%)\end{array}$ & $\begin{array}{c}\text { Oil } \\
\text { ratio } \\
(\%)\end{array}$ & $\begin{array}{l}\text { Pod yield } \\
\text { hectare }^{-1}\end{array}$ \\
\hline Year & 1 & $7.023^{\mathrm{ns}}$ & $101.376 * *$ & $53901.734 * *$ & $44.428 * *$ & $639.216^{* *}$ & $306928.83 * *$ \\
\hline Treatment & 13 & $29.009 * *$ & $89.346 * *$ & $871.835 * *$ & $19.492 * *$ & $20.286 * *$ & $9644.77 * *$ \\
\hline Treat $x$ Year & 13 & $0.262^{\mathrm{ns}}$ & $2.753^{\mathrm{ns}}$ & $67.976^{\mathrm{ns}}$ & $0.591^{\mathrm{ns}}$ & $2.919^{\mathrm{ns}}$ & $553.94 * *$ \\
\hline Error & 54 & $5.004^{\mathrm{ns}}$ & $9.148^{\mathrm{ns}}$ & $58.60^{\mathrm{ns}}$ & $0.719^{\mathrm{ns}}$ & $5.192^{\mathrm{ns}}$ & $145.70^{\mathrm{ns}}$ \\
\hline
\end{tabular}

**: significant at the $\mathrm{p} \leq 0.05$ probability level

ns: not significant

Table 4 shows the mean values obtained from the effects of bacterium and nitrogen dose applications that were used in the experiment on the number of pod per plant, the pod weight, the 100 pod weight, protein ratio, oil ratio and the emerging groups according to LSD (5\%) test. At the same time the interaction of years $\mathrm{x}$ applications for pod yield per hectare is given in Table 4 . The effects of the examined parameters over the years are shown in Table 5 also.

Table 4. Means of the number of pod plant $^{-1}$, the pod weight plant ${ }^{-1}$, the 100 pod weight, protein ratio, oil ratio, the pot yield hectare 1 and the emerging groups.

\begin{tabular}{|c|c|c|c|c|c|c|c|c|}
\hline \multirow{2}{*}{ 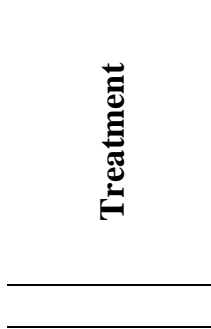 } & \multirow{2}{*}{ 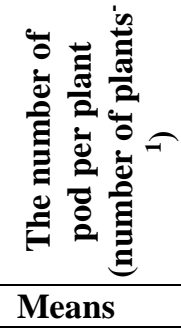 } & \multirow{2}{*}{ 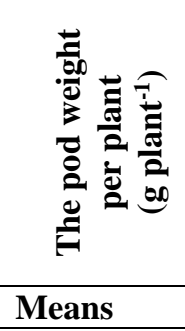 } & \multirow{2}{*}{ 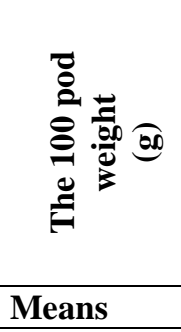 } & \multirow{2}{*}{ Means } & \multirow{2}{*}{ Means } & \multicolumn{3}{|c|}{ Pod yield per hectare $\left(\mathrm{kg} \mathrm{ha}^{-1}\right)$} \\
\hline & & & & & & 2015 & 2016 & Means \\
\hline Control & $20.9 \mathrm{~g}$ & $52.8 \mathrm{e}$ & $265.4 \mathrm{f}$ & 22.41 & 45.4 & $5257 \mathrm{jjk}$ & 4147 o & 4702 \\
\hline Bacterium (B) & $21.9 \mathrm{fg}$ & $54.7 \mathrm{e}$ & $269.2 \mathrm{f}$ & $23.2 \mathrm{~h} 1$ & 47.0 & 566 h1 & 4343 no & 4855 \\
\hline $40 \mathrm{~N}$ & $22.4 \mathrm{efg}$ & $58.7 \mathrm{~d}$ & $278.4 \mathrm{e}$ & $23.6 \mathrm{gh}$ & 48.2 & $5757 \mathrm{f}$ & $4424 n$ & 5091 \\
\hline $40 \mathrm{~N}+\mathrm{B}$ & $22.9 \mathrm{defg}$ & $60.4 \mathrm{~cd}$ & $281.4 \mathrm{de}$ & $24.4 \mathrm{fg}$ & 48.9 & $6104 \mathrm{e}$ & $4767 \mathrm{~m}$ & 5436 \\
\hline $80 \mathrm{~N}$ & $24.3 \mathrm{cdef}$ & $62.2 \mathrm{bc}$ & $291.0 \mathrm{bc}$ & $24.7 \mathrm{f}$ & 50.6 & $6195 \mathrm{de}$ & $4805 \mathrm{~m}$ & 5500 \\
\hline $80 \mathrm{~N}+\mathrm{B}$ & $24.9 \mathrm{bcde}$ & $62.5 \mathrm{bc}$ & $294.7 \mathrm{abc}$ & $25.2 \mathrm{ef}$ & 51.2 & 6250 bcde & $4866 \mathrm{~m}$ & 5558 \\
\hline $120 \mathrm{~N}$ & $25.4 \mathrm{abcd}$ & $62.9 \mathrm{bc}$ & $296.4 \mathrm{abc}$ & $25.8 \mathrm{de}$ & 50.4 & $6354 \mathrm{abcd}$ & $5081 \mathrm{kl}$ & 5718 \\
\hline $120 \mathrm{~N}+\mathrm{B}$ & $26.8 \mathrm{abc}$ & $64.0 \mathrm{ab}$ & $298.6 \mathrm{abc}$ & $26.0 \mathrm{de}$ & 49.5 & $6365 \mathrm{abcd}$ & $5157 \mathrm{jk}$ & 5761 \\
\hline $160 \mathrm{~N}$ & $26.8 \mathrm{abc}$ & $64.3 \mathrm{ab}$ & $299.8 \mathrm{ab}$ & $26.3 \mathrm{~cd}$ & 47.9 & $6372 \mathrm{abcd}$ & $5281 \mathrm{ij}$ & 5826 \\
\hline $160 N+B$ & $27.3 \mathrm{ab}$ & $64.6 \mathrm{ab}$ & $300.4 \mathrm{a}$ & $27.0 \mathrm{bc}$ & 47.3 & $6404 a b c$ & $5295 \mathrm{ij}$ & 5850 \\
\hline $200 N$ & $27.8 \mathrm{a}$ & $66.5 \mathrm{a}$ & $300.3 \mathrm{a}$ & $27.1 \mathrm{bc}$ & 47.2 & $6438 a b$ & $5581 \mathrm{fg}$ & 6009 \\
\hline $200 N+B$ & $25.1 \mathrm{bcd}$ & $64.3 \mathrm{ab}$ & $302.2 \mathrm{a}$ & $27.7 \mathrm{ab}$ & 46.4 & $6464 \mathrm{a}$ & $5538 \mathrm{gh}$ & 6001 \\
\hline $240 \mathrm{~N}$ & $23.8 \mathrm{def}$ & $62.6 \mathrm{bc}$ & $296.9 \mathrm{abc}$ & $27.8 \mathrm{ab}$ & 46.4 & $6364 \mathrm{abcd}$ & $4928 \mathrm{~lm}$ & 5646 \\
\hline $240 \mathrm{~N}+\mathrm{B}$ & $22.3 \mathrm{fg}$ & $61.5 \mathrm{bcd}$ & $290.1 \mathrm{~cd}$ & $28.1 \mathrm{a}$ & 46.1 & 6228 cde & $4781 \mathrm{~m}$ & 5505 \\
\hline $\mathbf{L S D}\left(\% 5_{A}\right)$ & $\mathrm{ns}$ & 1.32 & 3.34 & 0.37 & 0.99 & & 52.7 & \\
\hline $\operatorname{LSD}\left(\% 5_{B}\right)$ & 2.58 & 3.49 & 8.83 & 0.98 & ns & & 139.3 & \\
\hline
\end{tabular}

Table 5. Means of the pod weight plant ${ }^{-1}$, the 100 pod weight, protein ratio, oil ratio, the pod yield hectare ${ }^{-1}$ and their comparison groups according to LSD test in 2015 and 2016

\begin{tabular}{lccc}
\hline \multirow{2}{*}{ Characteristics } & \multicolumn{2}{c}{ Years } & \multirow{2}{*}{ LSD (p<0.05) } \\
\cline { 2 - 3 } & $\mathbf{2 0 1 5}$ & $\mathbf{2 0 1 6}$ & 1.32 \\
The pod weight per plant $\left(\mathrm{g} \mathrm{plant}^{-1}\right)$ & $62.7 \mathrm{~A}$ & $60.5 \mathrm{~B}$ & 3.34 \\
The 100 pod weight $(\mathrm{g})$ & $315.7 \mathrm{~A}$ & $265.0 \mathrm{~B}$ & 0.37 \\
Protein ratio $(\%)$, & $24.9 \mathrm{~B}$ & $26.4 \mathrm{~A}$ & 0.99 \\
Oil ratio $(\%)$ & $25.7 \mathrm{~B}$ & $50.8 \mathrm{~A}$ & 52.7 \\
Pod yield per hectare $\left(\mathrm{kg} \mathrm{ha}^{-1}\right)$ & $6137 \mathrm{~A}$ & $4928 \mathrm{~B}$ & \\
\hline
\end{tabular}


Upon analysing the mean values of two years for number of pod per plant, the highest value has been identified to be obtained from the application of $200 \mathrm{~N}$ $\left(27.8\right.$ plants $\left.^{-1}\right)$, which is followed by $160 \mathrm{~N}+\mathrm{B}(27.3$ plants $\left.{ }^{1}\right), 160 \mathrm{~N}\left(26.8\right.$ plants $\left.^{-1}\right), 120 \mathrm{~N}+\mathrm{B}\left(26.8\right.$ plants $\left.^{-1}\right)$ and $120 \mathrm{~N}$ (25.4 plants $^{-1}$ ) applications. The high dose of nitrogen and the bacterium $(240 \mathrm{~N}+\mathrm{B})$ application adversely affected the number of pod per plant. Considering the combined results of two years, depending on nitrogen applications increased the number of pod per plant compared to the control. On the other hand, bacterium inoculation has been found to have an effect on increasing the number of pod. The high nitrogen doses applied during the planting and maximum flowering period increased the green parts of vegetative component, yet it led to the low binding rates of the flowers and the flowers could not penetrate into soil due to gynophore. The emergence of gynophore increased depending on the formation of flowers only in the plots to which nitrogen application was performed $(200 \mathrm{~N}=27.8$ plants $^{-1}$ ), and thus the number of pod per plant increased. Similar results have emerged in the studies conducted by Hiltbold et al. (1983), Dahatonde (1982), Lim and Hamdan (1984), Seluk (1992), Agcan (2010), ElHabbasha et al. (2013). They have indicated that there is a positive relationship between planting, maximum flowering, nitrogen fertilizer application performed at the end of flowering and the number of pod per plant.

When the average values of two years for pod weight per plant were examined, the highest mean was obtained from $200 \mathrm{~N}(66.5 \mathrm{~g})$ application, while the lowest mean was obtained from control (52.8 g) and bacteria (54.7 g) inoculations in the same group (Table 4). Nitrogen application at a dose of $200 \mathrm{~N}$ increased the pod weight per plant, while the pod weight per plant was found to be the lowest in the control plot. Increasing doses of $\mathrm{N}$ fertilizer were effective in increasing the maximum flowering and pod weight per plant. Nitrogen fertilizer application has a positive effect on the rate of pod weight (Tiwari and Dhakar, 1997; Lim and Hamdan, 1984; Gohari and Niyaki, 2010; El-Habbasha et al., 2013; Farag and Zahran, 2014). Mahmowd et al. (2014) have noted that different from these findings, Reddy and Tanner (1980) and Hiltbold et al. (1983) have stated that bacterium inoculation increases the weight of pod when applied together with $\mathrm{N}$ fertilizer. The number of pod weight per plant was higher in 2015 .

The bacteria and increasing nitrogen doses affected the values of 100 fruit weight positively, while the applications above $200 \mathrm{~N}+\mathrm{B}$ treatments negatively affected the 100 pod weight (Table 4). When the mean values of two years have been examined, the highest 100 pod weight values have been obtained from $200 \mathrm{~N}+\mathrm{B}(302.2$ g), $160 \mathrm{~N}+\mathrm{B}(300.4 \mathrm{~g})$ and $200 \mathrm{~N}$ (300.3 g). Selcuk (1992) has indicated that the highest value with $202.25 \mathrm{~g}$ was obtained from $150 \mathrm{~kg} \mathrm{~N}^{-1}$ applied at three different times with $202.25 \mathrm{~g}$ in terms of 100 pod weight, while the lowest value $185.15 \mathrm{~g}$ was obtained from the application in which seed inoculation and control (0) nitrogen dose were used. Tiwari and Dhakar (1997) have determined that the increasing nitrogen fertilizer increased 100 pod weight. Agan (2010) has reported that nitrogen fertilizer applications at different doses and times are effective on 100 pod weight, and bacterium inoculation has a little effect on the 100 pod weight. Likewise, the increase in nitrogen fertilizer increased 100 pod weight (Taylor and Moshrefi, 1987; Selcuk, 1992; Tiwari and Dhakar, 1997; Agan, 2010). In contrast, Sajid et al. (2011) have found that Rhizobium inoculation significantly affected the yield and growth parameters.

The effects of bacteria and nitrogen doses on protein ratio (\%) and their groups according to the LSD (5\%) test are given in Table 4 . The mean values of two years in terms of protein ratio suggested that the highest protein ratio was obtained from $240 \mathrm{~N}+\mathrm{B}(28.1 \%)$; whereas the mean lowest protein ratio belongs to control $(22.4 \%)$ plots (Table 4). High dose nitrogen fertilizer application, which is used in planting and maximum flowering period, has significantly increased the protein content of the seed. High level of protein content in peanut types to be considered as a snack is a desirable feature. Ardahanli (1997), Zhou et al. (2007), Agan (2010), The nitrogen fertilizer applied at different doses and times is substantially effective in increasing protein ratio (Xiang et al., 2011; El-Habbasha et al., 2013; Farag and Zahran, 2014). Reddy and Tanner (1980) have clarified that $N$ fertilizer applied at different times and doses is not effective alone; however, when used with the bacterium, it influences the protein content of the seed. Karakoc (1995) determined a high protein ratio in applications of $40 \mathrm{~kg} \mathrm{ha}^{-}$ ${ }^{1}$ nitrogen dose and $500 \mathrm{~g}$ bacteria inoculation $100 \mathrm{~kg}^{-1}$ seeds.

The nitrogen applications and bacterium inoculation have been determined to affect the oil ratio (Table 4). The effects of the treatments were found to be insignificant. However, difference between years has been significant. The oil ratio obtained in year 2016 are higher than year 2015 (Table 5).

The high oil content in the seed and increasing the oil quality is a considerable feature required by the oil industry. The research findings are consistent with those of some studies. Sharma et al. (2011) have revealed that the maximum oil content of NC-92 and IRG-40 peanut varieties treated with Rhizobia viz. is higher than uninoculated peanuts. Singh and Ahuja (1985) have detected that $25 \mathrm{~kg} \mathrm{~N} \mathrm{ha-1}$ and bacterium inoculation increased the oil ratio in the seed. Moreover, Abraham and Eleiwa (2008), Agan (2010), Xiang et al. (2011), Farag and Zahran (2014) have emphasized that increasing nitrogen doses would increase the oil ratio. Hasan and Sahid (2016) have indicated that the highest oil ratio value is taken from the plots where bacterium, nitrogen and phosphorus combinations are applied. Contrary to these findings, Ardahanli (1997), gave nitrogenous fertilizer to the peanut plant in the form of ammonium sulfate in a single level and determined that the amount of oil in peanut reduced. Caliskan and Arioglu (2001) have found that the applications of bacterium inoculation and nitrogen 
doses had a significant effect on all properties of the seed, except for the oil content of peanuts.

The analysis of variance indicated that years (factor A) bacterium and nitrogen doses (factor B), years and nitrogen fertilizer and bacterium (factor A x B) interaction were significantly affected by pot yield in both years (Table 3). The highest yield per hectare was obtained from $200 \mathrm{~N}+\mathrm{B}(6434 \mathrm{~kg})$ applications in 2015 , the lowest yield per hectare was obtained from control $(4702 \mathrm{~kg})$ in 2016. In the first year, pod yield per hectare was higher than in the second year. The main reason for the decrease in yield is low soil $\mathrm{N}$ content which the experiment was conducted in 2016 (Table 4). This result is also related to climate factors such as precipitation. Mahalle et al. (1992) have found that $25 \mathrm{~kg} \mathrm{~N} \mathrm{ha}^{-1}$ increased pod yield from $1520 \mathrm{~kg}$ $\mathrm{ha}^{-1}$ to $1750 \mathrm{~kg} \mathrm{ha}^{-1}$, and $50 \mathrm{~kg} \mathrm{~N} \mathrm{ha}^{-1}$ had no significant effect on pod yield. Agan (2010), Dahatonde (1984), Tiwarive Dhakar (1997), Barik et al. (1998), Hossain and Hamid (2007), Gohari and Niyaki (2010), Xiang et al. (2011), El-Habbasha et al. (2013), Farag and Zahran (2014) have identified that high-dose nitrogen applications provided the highest pod yield. Conversely, Cobb and Whitty (1973), Hickey et al. (1974), Sharma et al. (2011) have put forward that pod yield increased in peanuts grown by inoculating bacterium. Besides, Hiltbolt et al. (1983), Caliskan and Arioglu (2001), Sogut et al. (2013) have found that bacterium inoculation and $\mathrm{N}$ fertilizer increased pod yield.

\section{CONCLUSIONS}

The nutrient requirement of the plant in terms of yield is $200 \mathrm{~kg} \mathrm{ha}^{-1}$ nitrogen in total including $40 \mathrm{~kg} \mathrm{ha}^{-1}$ nitrogen during plantation, $80 \mathrm{~kg} \mathrm{ha}^{-1}$ before the first irrigation, $80 \mathrm{~kg} \mathrm{ha}^{-1}$ before the second irrigation in Virginia type (Halisbey) peanut cultivation under main crop conditions in Cukurova region. An alternative to this application is the second application that requires $200 \mathrm{~kg}$ $\mathrm{ha}^{-1}$ nitrogen (ammonium nitrate $33 \%$ ) and bacterium $(200 \mathrm{~N}+\mathrm{B})$ in total including bacterium and $40 \mathrm{~kg} \mathrm{ha}^{-1}$ nitrogen during plantation, $80 \mathrm{~kg}$ ha before the first irrigation, $80 \mathrm{~kg} \mathrm{ha}^{-1}$ before the second irrigation.

\section{ACKNOWLEDGEMENTS}

This research was supported by The Scientific Research Projects Unit of Cukurova University (Project No: FDK-2015-4957).

\section{LITERATURE CITED}

Agan, Y.A. 2010. The effects of different amount of nitrogen in different periods on the yield and some agricultural characteristics of peanut grown as main crop. Cukurova University Faculty of Agriculture, Ms. Thesis 72 pages, Adana, Turkey.

Andersen, P.C., K. Hill, D.H. Gorbet and B.V. Brodbeck. 1998. Fatty acid and amino acid profiles of selected peanut cultivars and breeding lines. J. Food Composition and Analysis. 11:100-111.

Barik, A.K., A.K. Mukherjee and B.K. Mandal. 1998. Growth and yield of sorghum and groundnut grown as sole and intercrop under different nitrogen regimes. Indian J. Agron. 43 (4): 37-42.

Boydak, E., D. Karaaslan and H. Turkoglu. 2010. The effect of different nitrogen and irrigation levels on fatty acid composition of peanut oils. Turkish Journal of Field Crops 15(1): 29-33.
Cobb, L.C. and E.B. Whitty. 1973. Response of peanuts to inoculation with nitrogen-fixing bacteria. Proc. Am. Peanut Res. Edu. Assn. 5:211-12.

Caliskan, S. and H.H. Arioglu. 2001. The effect of bacteria (Rhizobium sp.) and nitrogen fertilizer applications on yield and quality characteristics of peanut grown, Turkey IV. Field Crops Congress, September 17-21, Tekirdag, Vol: 2, p: 303-306.

Dahatonde, B.N. 1982. Effect of nitrogen and phosphate fertilization on yield and yield contributory characters of groundnut, Punjab Krishi Vidhya Peeth Res. J. 61 (1): 31-33.

Dahatonde, B.N. 1984. Effect of nitrogen and phosphate fertilization on yield and yield contributory characters of ground (Arachis hypogaea L.). Field Crop Abs, Vol. 37 No.11.

Davis, J.P., L.O. Dean, W.H. Faircloth and T.H. Sanders. 2008. Physical and chemical characterizations of normal and high-oleic oils from nine commercial cultivars of peanut. J. Amer. Oil Chem. Soc. $85: 235-243$

Dingil, M., S. Senol and M.E. Oztekin. 2008. Updating detailed soil surveys and maps by using geographic information system (CBS) of Cukurova University Campus Area. Scientific Research Projects (Final Report), Project Number: ZF2005BAP8.

El-Habbasha, S.F., M.H. Taha and N.A. Jafar. 2013. Effect of nitrogen fertilizer levels and zinc foliar application on yield, yield attributes and some chemical traits of groundnut. Research Journal of Agriculture and Biological Sciences 9 (1): 1-7.

Farag, A.A.I. and A.A. Zahran. 2014. Groundnut (Arachis hypogaea L.) growth and yield responses to seed irradiation and mineral fertilization. Journal of Agriculture and Veterinary Science 7(5): 6370.

Gohari, A.A. and N.S.A. Niyaki. 2010. Effects of iron and nitrogen fertilizers on yield and yield components of peanut (Arachis hypogaea L.) in Astaneh Ashrafiyeh, Iran. American-Eurasian J. Agric. and Environ. Sci. 9 (3): 256-262.

Hassan, F.U., R.A. Ahmad and G. Oadir. 2003. Oil and fatty acid composition of sunflower in response to seasonal variation. Helia. 23: $121-8$.

Hassan, F.U., A. Manaf and M. Ejaz. 2005. Determinants of oil and fatty acid accumulation in peanut Int. J. Agri. Biol. 7: 895-899.

Hickey, J.M., W.K. Robertson, D.H. Hubbell and E.B. Whitty. 1974. Inoculation, liming, and fertilization of peanuts on Lakeland fine sand. Soil Crop Sci. Soc. Fla. Proc. 33:218-222.

Hiltbold, A.E., D.L. Hartzog, R.B. Harrison and F. Adams. 1983. Inoculation of peanuts on farmers' fields in Alabama. Peanut Science 10:79-82.

Hossain, M.A. and A. Hamid. 2007. Influence of $\mathrm{N}$ and $\mathrm{P}$ fertilizer application on root growth, leaf photosynthesis and yield performance of groundnut. Bangladesh J. Agri. Res. 32(3): 369-374.

Lim, E.S. and O. Hamdan. 1984. The Reproductive characters of four varieties of groundnuts (Arachis hypogaea L.). Pertanika 7(3): 2531.

Ly, Z., L. Xd, T. X, L. Y.J. and L. Zf. 2007. Effects of different application amount of $\mathrm{N}, \mathrm{P}, \mathrm{K}$ fertilizers on physiological characteristics, yield and kernel quality of peanut. Ying Yong Sheng Tai Xue Bao. 18 (11): 2468-74.

Mahalle, S., O.P. Singh and C.V. Sawant. 1992. Effect of different levels of nitrogen and phosphorus on different varieties of groundnut. C.A.B. Prompts Groundnuts.

Mahmowd, M.W.S.H., F.S.H. Sedeck, E.E.E. Khafagy and I.S.M.J. Mosaad. 2014. Effect of applied N, P and K on peanut yield, quality and nutrients uptake in sandy soils. Soil Sci. and Agric. Eng., Mansoura Univ. 5 (8): 6141-6154.

Reddy, V.M. and J.W. Tanner. 1980. The effects of irrigation inoculants and fertilizer nitrogen on peanuts. Peanut Science 7: 114-119.

Selcuk, S. 1992. A study on the the effect of bacteria (Rhizobium sp.) and nitrogen fertilizer applications on yield and quality characteristics of peanut grown, Çukurova University, Faculty of Agriculture, Ms. Thesis, p:74, Adana, Turkey.

Sharma, P., V. Sardana and S.S. Kandola. 2011. Response of groundnut (Arachis hypogaea L.) to rhizobium inoculation. Libyan Agriculture Research Center Journal International 2 (3):101-104.

Shin, E.C., B.D. Craft, R.B. Pegg, R.D. Phillips and R.R. Eitenmiller. 2010. Chemometric approach to fatty acid profiles in runner type peanut cultivars by principal component analysis (PCA). Food Chem. 119:1262-1270.

Sogut, T., F. Ozturk, M.G. Temiz, O. Toncer and Z.B. Onat. 2013. The Effects of rhizobial inoculation and nitrogen fertilizer application on 
nodulation, yield and yield components of groundnut (Arachis hypogaea L.). Global Journal on Advances Pure and Applied Sciences 1:158-167.

Taylor, R.G. and K. Moshrefi. 1987. Calcium, nitrogen and rhizobium effects on (Arachis hypogaea L.) Valencia C. Peanut Science 14:3133
Tiwari, R.B. and L.L. Dhakar. 1997. Productivity and economics of summer groundnut (Arachis hypogaea L.) as affected by irrigation, fertilizes and weed control. Indian J. Agron. 42(3): 490-494.

Weiss, E.A. 2000. Oilseed Crops. Blackwell Science Ltd. Paris, Tokyo, Berlin, Victoria.

Xiang, Z, Z. Xin-you, M. Jia-Wei and Z. Yu-Ting. 2011. Effect of nitrogen fertilization on yield and quality of different peanut cultivars. Plant Nutrition and Fertilizer Science 17 (6): 1417-1423. 